\title{
Probable Association between Nocardial Infections and Parkinson's Disease
}

\section{Masoud Keikha*}

Department of Microbiology, School of Medicine, Isfahan University of Medical Sciences, Isfahan, Iran

\section{ABSTRACT}

Introduction: Parkinson's disease is one of the most common chronic disorders of the central nervous system. Genetic and environmental factors are known as risk factors for this disease. Conclusion: Several investigations have shown that infectious diseases, especially central nervous system nocardiosis, are likely to contribute to the onset of this disease.

*Corresponding Author: Masoud Keikha

E-mail: masoudkeikha@outlook.com 
وابستگى احتمالى ميان عفونتهاى نوكارديايى و بيمارى ياركينسون

مسعود كيخا"

كروه ميكروب شناسى، دانشكده يزشكى، دانشًاه علوم يزشكى اصفهان، اصفهان، ايران

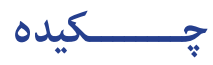

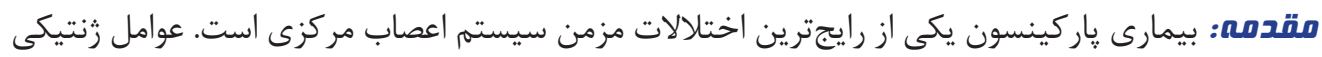

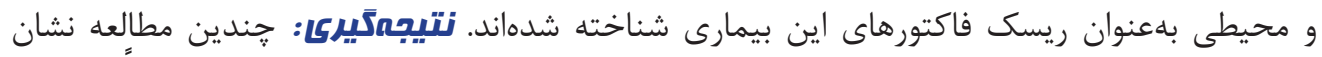

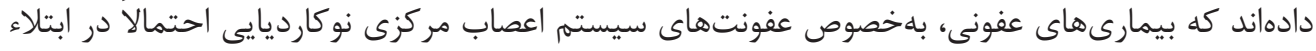
به اين بيمارى نقش دارند.

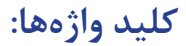

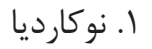

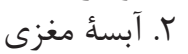

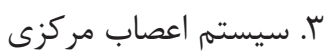




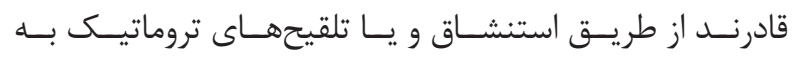

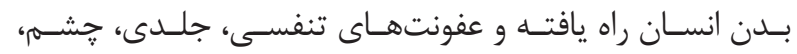

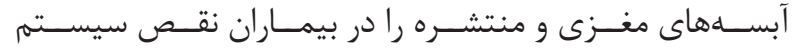

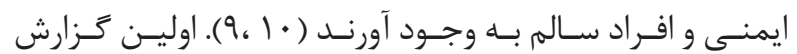

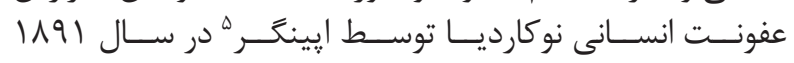

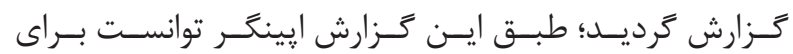

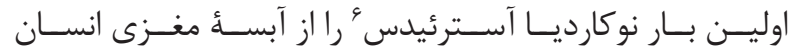

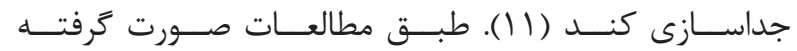

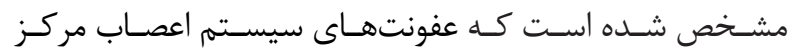

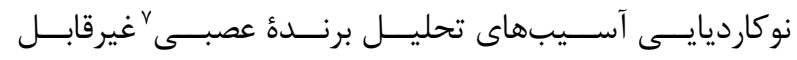

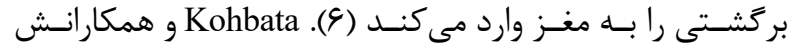

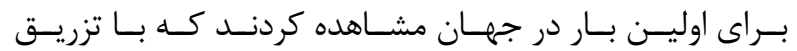

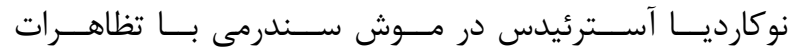

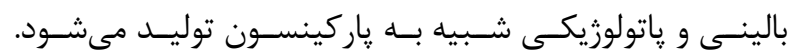

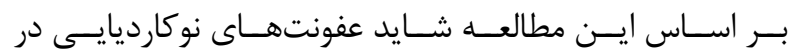

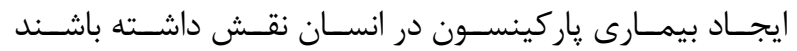

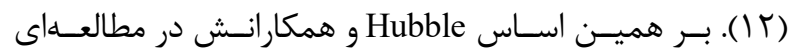

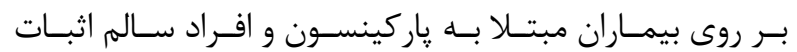

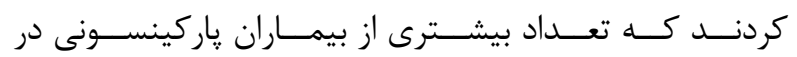

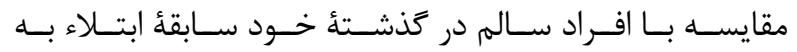

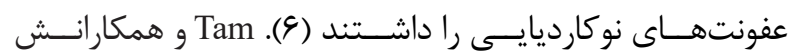

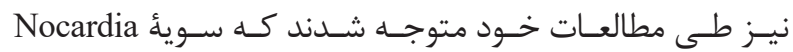
asteroids GUH-2

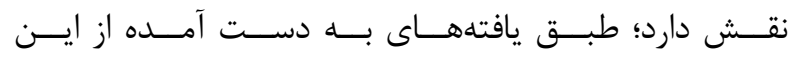

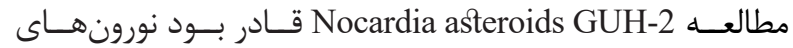

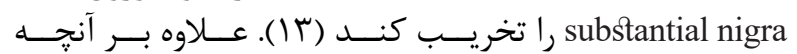

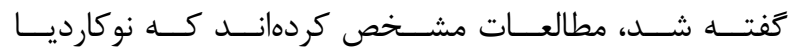

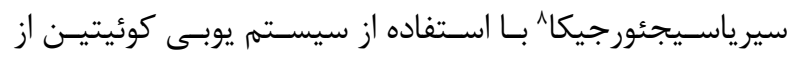

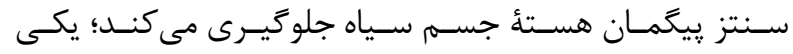

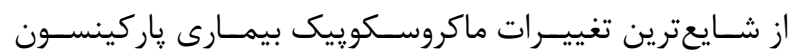

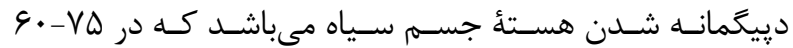

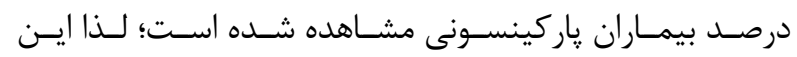

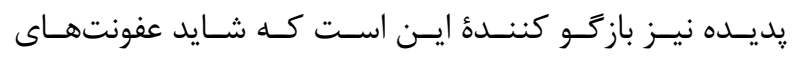

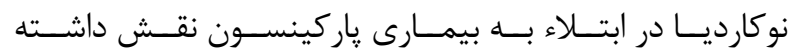

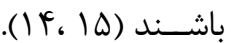

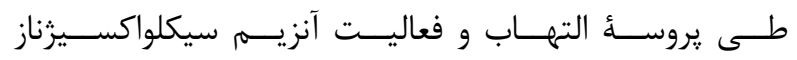

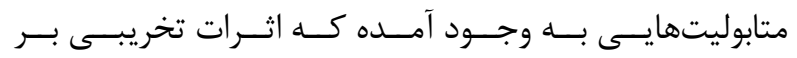

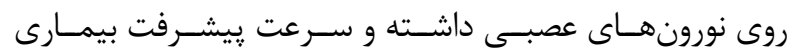

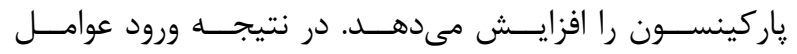

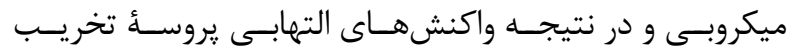

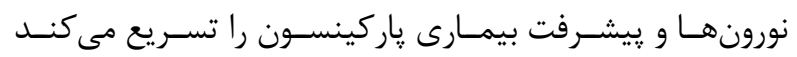

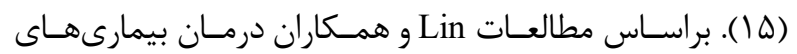

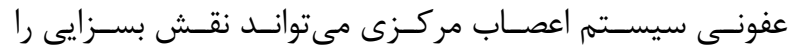

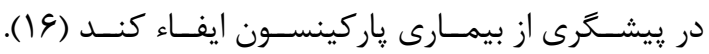

${ }^{1}$ Substantia nigra pars compacta

${ }^{2}$ Nocardia spp

${ }^{3}$ Helicobacter pylori

${ }^{4}$ Streptomyces Venezuela

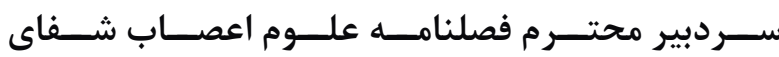

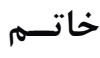

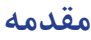

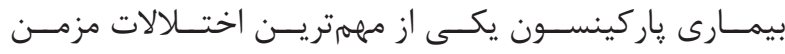

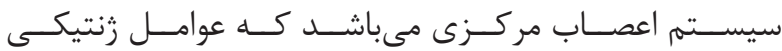

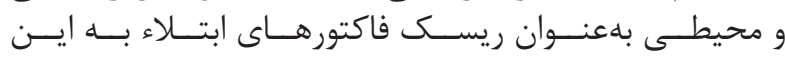

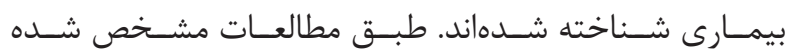

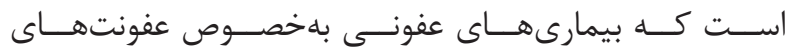

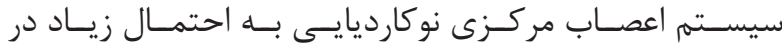

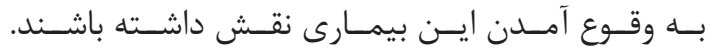

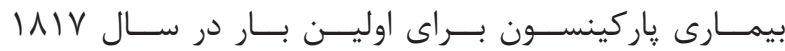

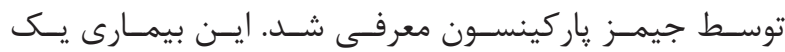

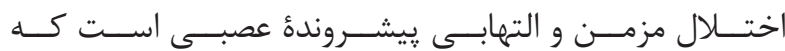

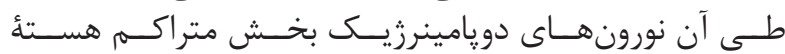

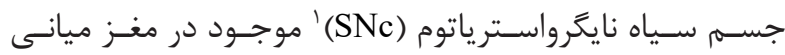

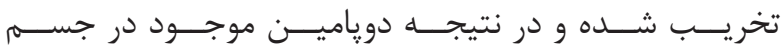

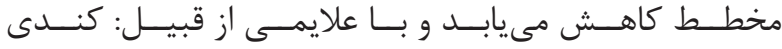

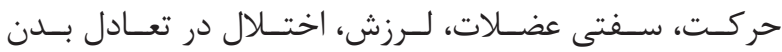

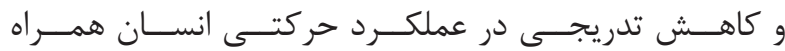

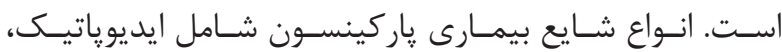

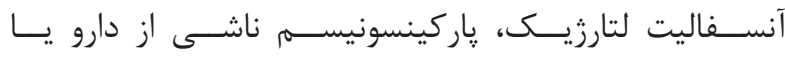

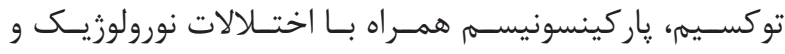

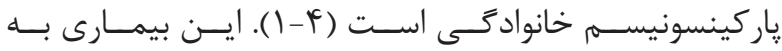

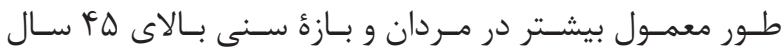

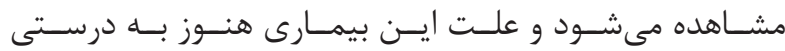

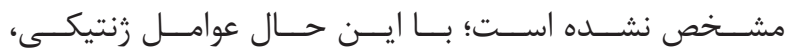

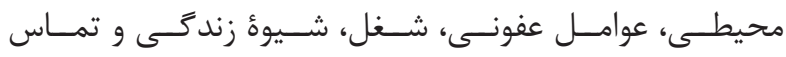

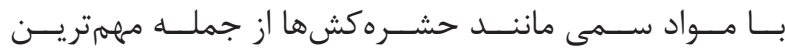

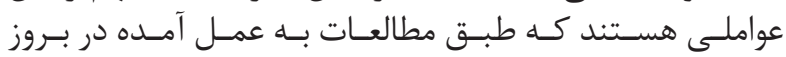

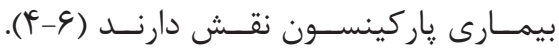

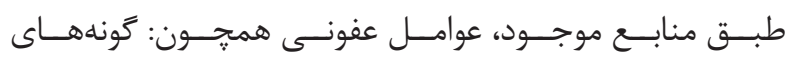

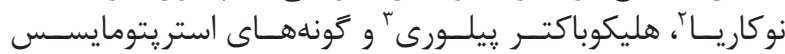

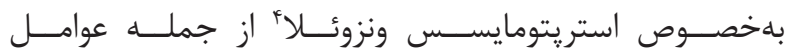

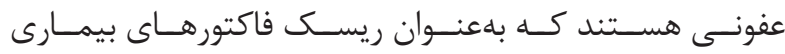

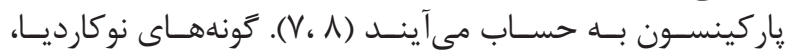

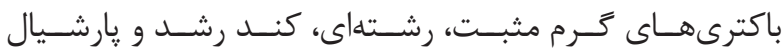

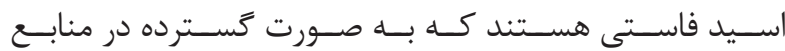

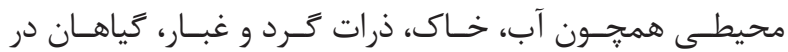

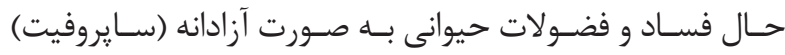

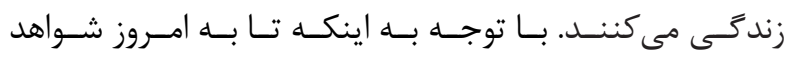

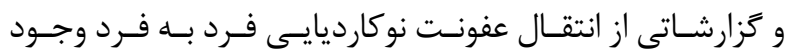

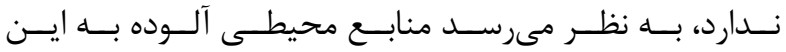

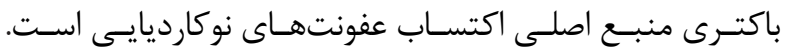

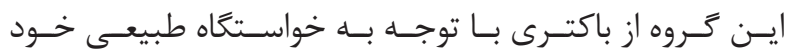

${ }^{5}$ Eppinger

${ }^{6}$ Nocardia asteroids

${ }^{7}$ Neurodegenerative

${ }^{8}$ Nocardia cyriacigeorgica 


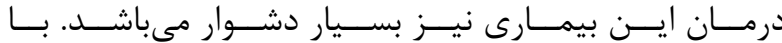

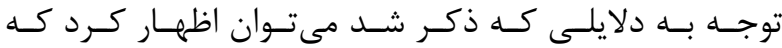

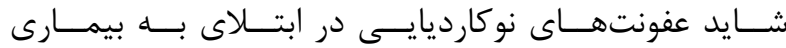

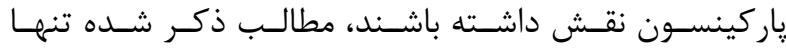

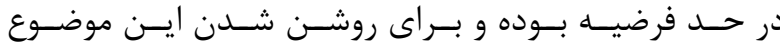

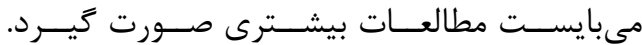

1. Kozina E, Khaindrava V, Kudrin V, Kucherianu V, Klodt P, Bocharov E, et al. Experimental modeling of functional deficiency of the nigrostriatal dopaminergic system in mice. Ross Fiziol Zh Im I M Sechenova. 2010; 96(3): 270-82.

2. Lewis SJ, Barker RA. Understanding the dopaminergic deficits in Parkinson's disease: insights into disease heterogeneity. J Clin Neurosci. 2009; 16(5): 620-5.

3. Martig AK, Mizumori SJ. Ventral tegmental area and substantia nigra neural correlates of spatial learning. Learn Mem. 2011; 18(4): 260-71.

4. Nakamura T, Kanayama R, Sano R, Ohki M, Kimura $\mathrm{Y}$, Aoyagi M, et al. Quantitative analysis of ocular movements in Parkinson's disease. Acta Otolaryngol. 1991; 111(481): 559-62.

5. Taylor K, Counsell C, Gordon J, Harris C. Screening for undiagnosed parkinsonism among older people in general practice. Age Ageing. 2005; 34(5): 501-4.

6. Hubble JP, Cao T, Kjelstrom JA, Koller WC, Beaman BL. Nocardia species as an etiologic agent in Parkinson's disease: serological testing in a case-control study. J Clin Microbiol. 1995; 33(10): 2768-9.

7. Liu B, Gao H-M, Hong J-S. Parkinson's disease and exposure to infectious agents and pesticides and the occurrence of brain injuries: role of neuroinflammation. Environ Health Perspect. 2003; 111(8): 1065-73.

8. Caldwell KA, Tucci ML, Armagost J, Hodges TW, Chen J, Memon SB, et al. Investigating bacterial sources of toxicity as an environmental contributor to dopaminergic neurodegeneration. PLoS One. 2009; 4(10): e7227. doi: 10.1371/journal.pone.0007227.

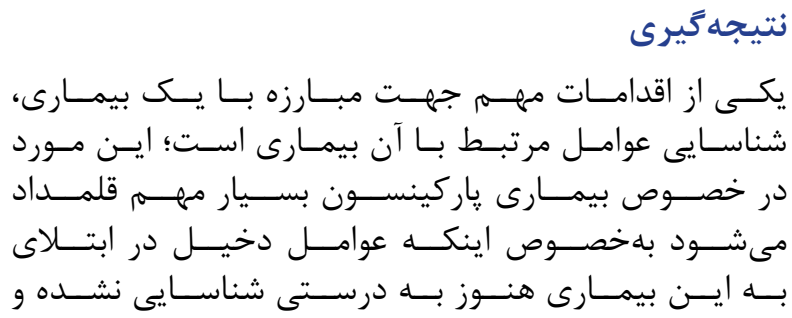

منابع

9. Brown-Elliott BA, Brown JM, Conville PS, Wallace RJ. Clinical and laboratory features of the Nocardia spp. based on current molecular taxonomy. Clin Microbiol Rev. 2006; 19(2): 259-82.

10. Dominguez DC, Antony SJ. Actinomyces and nocardia infections in immunocompromised and nonimmunocompromised patients. J Natl Med Assoc. 1999; 91(1): 35-9.

11. Ogata SA, Beaman BL. Site-specific growth of Nocardia asteroides in the murine brain. Infect Immun. 1992; 60(8): 3262-7.

12. Kohbata S, Beaman BL. L-dopa-responsive movement disorder caused by Nocardia asteroides localized in the brains of mice. Infect Immun. 1991; 59(1): 181-91.

13. Tam S, Barry D, Beaman L, Beaman B. Neuroinvasive Nocardia asteroides GUH-2 induces apoptosis in the substantia nigra in vivo and dopaminergic cells in vitro. Exp Neurol. 2002; 177(2): 453-60.

14. Martinot B. Separating and chracterizing products generated by Nocardia cyriacigeorgica. Biological. 2009.

15. Shafiee Ardestani M, Fathi Moghaddam H, Hemmati A, Nazari Z. Effect of Cyclooxygenase-2 inhibition on rigidity of animal model of Parkinson's disease. Tehran Univ Med J. 2008; 66(5): 299-304.

16. Lin S-K, Lu C-S, Vingerhoets F, Snow BJ, Wai $\mathrm{Y}-\mathrm{Y}$, Chu N-S, et al. Isolated involvement of substantia nigra in acute transient parkinsonism: MRI and PET observations. Parkinsonism Relat Disord. 1995; 1(2): 67-72. 